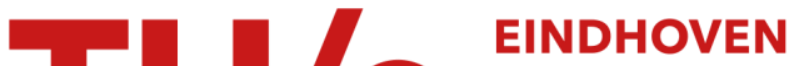

\section{Methodologies for information systems investment evaluation : a comparative review}

\section{Citation for published version (APA):}

Renkema, T. J. W., \& Berghout, E. W. (1997). Methodologies for information systems investment evaluation : a comparative review. Information and Software Technology, 39(1), 1-13. https://doi.org/10.1016/09505849(96)85006-3

DOI:

10.1016/0950-5849(96)85006-3

Document status and date:

Published: 01/01/1997

\section{Document Version:}

Publisher's PDF, also known as Version of Record (includes final page, issue and volume numbers)

\section{Please check the document version of this publication:}

- A submitted manuscript is the version of the article upon submission and before peer-review. There can be important differences between the submitted version and the official published version of record. People interested in the research are advised to contact the author for the final version of the publication, or visit the $\mathrm{DOI}$ to the publisher's website.

- The final author version and the galley proof are versions of the publication after peer review.

- The final published version features the final layout of the paper including the volume, issue and page numbers.

Link to publication

\section{General rights}

Copyright and moral rights for the publications made accessible in the public portal are retained by the authors and/or other copyright owners and it is a condition of accessing publications that users recognise and abide by the legal requirements associated with these rights.

- Users may download and print one copy of any publication from the public portal for the purpose of private study or research.

- You may not further distribute the material or use it for any profit-making activity or commercial gain

- You may freely distribute the URL identifying the publication in the public portal.

If the publication is distributed under the terms of Article 25fa of the Dutch Copyright Act, indicated by the "Taverne" license above, please follow below link for the End User Agreement:

www.tue.nl/taverne

Take down policy

If you believe that this document breaches copyright please contact us at:

openaccess@tue.nl

providing details and we will investigate your claim. 


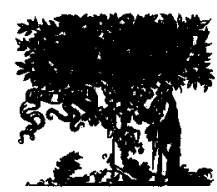

ELSEVIER

Information and Software Technology 39 (1997) 1-13

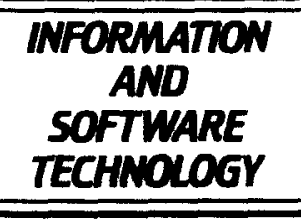

\title{
Methodologies for information systems investment evaluation at the proposal stage: a comparative review
}

\author{
Theo J.W. Renkema ${ }^{\mathrm{a}, *}$, Egon W. Berghout ${ }^{\mathrm{b}}$ \\ ${ }^{a}$ Eindhoven University of Technology, Section Information and Technology, Department of Industrial Engineering and Management Science, \\ PO Box 513, $5600 \mathrm{MB}$ Eindhoven, The Netherlands \\ ${ }^{\mathrm{b}}$ Section Information Systems, Delft University of Technology, Department of Technical Mathematics and Informatics, 2600 BL Delft, The Netherlands
}

Received 4 November 1994; revised 6 February 1996

\begin{abstract}
The evaluation of information systems (IS) investments has been a recognized problem area for the last three decades, but has recently gained renewed interest of both management and academics. IS investments constitute a large and increasing portion of the capital expenditures of many organizations. However, it is difficult to evaluate the contribution of an IS investment to the goals pursued. Consequently, there is a great call for methods and techniques that can be of help in evaluating IS investment at the proposal stage. The contribution of the paper to the problem area is twofold. First, the different concepts which are used in evaluation are discussed and more narrowly defined. When speaking about IS investments, concepts are used that originate from different disciplines. In many cases there is not much agreement on the precise meaning of the different concepts used. However, a common language is a prerequisite for the successful communication between the different organizational stakeholders in evaluation. In addition to this, the paper reviews the current methods and puts them into a frame of reference. All too often new methods and guidelines for investment evaluation are introduced, without building on the extensive body of knowledge that is already incorporated in the available methods. Four basic approaches are discerned: the financial approach, the multi-criteria approach, the ratio approach and the portfolio approach. These approaches are subsequently compared on a number of characteristics on the basis of methods that serve as examples for the different approaches. The paper concludes with suggestions on how to improve evaluation practice and recommendations for future research.
\end{abstract}

Keywords: Information systems investment evaluation; Evaluation methodologies; Information systems value

\section{Introduction}

Investments in information systems (IS) are large and increasing. They constitute up to $50 \%$ of the capital expenditures of large organizations [1-3]. Information systems are not only used in administrative and decision making tasks but are changing the shape of production processes and enable the development of new products and services. Recent empirical studies show that organizations have several problems with the evaluation of proposals for IS investments [4-8]. A number of causes can be identified. Because information systems are often for a great extent integrated in the organization, it is difficult to establish the boundaries of the system. For instance, which user costs of a new electronic mail system should be considered in an investment proposal?

\footnotetext{
* Corresponding author.
}

Another possible cause is the ongoing dispute on the relevant decision criteria. How should, for instance, long-term consequences of an IS investment be incorporated? An example of this is the contribution of a database management system to the realization of data infrastructure in an organization.

A plethora of methods and techniques has been proposed to assist in the evaluation of IS investment proposals. Different Dutch researchers in the universities of Delft, Eindhoven and Amsterdam $[9,10]$ identified over 65 methods that all aim to be of help in the evaluation of IS investment proposals (see Appendix). Already in 1961 the International Federation of Information Processing devoted its first conference to evaluation issues [11] and in 1968 Joslin wrote his book on computer selection [12].

However, all too often new methods and guidelines for IS investment evaluation are proposed, without building 
Table 1

Definitions

\begin{tabular}{llll}
\hline Consequences & & Positive & Negative \\
\hline Financial and non-financial & Value & Benefits & Sacrifices \\
Financial & Profitability (profits or losses) & Yieldings & Costs \\
& Return & Earnings & Expenditures \\
Non-financial & Contribution & Positive contribution & Negative contribution \\
\hline
\end{tabular}

on the extensive body of knowledge that is already incorporated in the available methods. The purpose of this paper is to improve insight into the current methods for the evaluation of IS investment proposals. For the moment this is the maximum that can be strived for, as research that has validated evaluation methods is hardly available. General prescriptions about the use of which method in which circumstances cannot be given. Current research is still focusing on finding the essential evaluation criteria, the circumstances in which these should be used and the inclusion of the criteria in the evaluation process.

Section 3 reviews the current methods. Subsequently, in Section 4 an assessment of the methods on different characteristics is presented. In the preceding Section 2 the different concepts used in evaluation are discussed and defined. This is prerequisite for the comparison of the methods in the following sections. Finally, Section 5 concludes with suggestions on how to improve evaluation practice and some recommendations for future research.

\section{Terminology}

\subsection{Necessity}

In order to be able to compare methods for the evaluation of IS investment proposals, one should avoid misinterpretations about the different concepts used. Also, in evaluation practice the communication between stakeholders in the evaluation process can be improved by the use of a common language. This section discusses and defines the concepts that are used in evaluation and in the remainder of the paper.

\subsection{Definitions}

Information systems often have significant consequences for the content and the shape of work in organizations. These consequences are not only visible in terms of money but also in changing conditions of work, new authorities, and so on.

This paper distinguishes financial ${ }^{1}$ and non-financial

\footnotetext{
${ }^{1}$ Because economic stands for a much wider perspective; see Berghout and Renkema [10].
}

consequences. Financial consequences are the consequences which can be expressed in monetary terms. Non-financial consequences cannot be expressed in monetary terms. For the latter we use the notion contribution. A consequence is seen as an event that arises from the introduction of the information system, starting with the decision to go ahead with the investment. An information system is defined as all components that together provide the necessary information. The components are: the hardware and the software, the people and the procedures with which they work, and the data that are processed by the system [13].

Financial and non-financial consequences together determine the value of an information system. Benefits refer to all positive consequences of an IS investment and sacrifices to all negative consequences.

With respect to financial consequences a further distinction is made between profitability and return. The return is determined by cash flow evaluation. Positive, incoming cash flows are earnings and negative, outgoing cash flows are expenditures. The profitability in terms of profits (positive) or losses (negative) is defined as the accounting registration of yieldings and costs. A sound financial evaluation of a proposed investment is based upon an analysis of the return and not on the profitability $[14,15]$. Table 1 gives an overview of the defined consequences.

In several methods risk is included as a separate criterion. In this paper risk is seen as a measure of uncertainty with respect to a specific consequence of an investment. This uncertainty can, for example, be expressed in terms of the chances that the expected expenditures will be higher or the expected earnings will be lower. This implies that risk refers to every consequence of an IS investment.

\section{Evaluating IS investments proposals: review of methods}

Different authorities have given an overview of the available methods for the evaluation of IS investment proposals [16-19]. This paper distinguishes four basic approaches that can be recognized in the many methods proposed.

Renkema [20] recognizes, apart from the approach that only considers financial consequences, three 
non-financial approaches. This leaves the following four approaches:

- The financial approach.

- The multi-criteria approach.

- The ratio approach.

- The portfolio approach.

The different approaches are successively reviewed. Of each approach a number of methods are discussed in more detail. Some of the methods are marked by several approaches, therefore we made a division of methods into approaches on the basis of characteristics that were perceived as predominant. The requirements for discussion of a method were:

- The method should be well documented and accessible for further analysis.

- The method should be well structured. This implies that a method consisting of mere guidelines is insufficient to be discussed ${ }^{2}$.

- The method should be characteristic of the approach reviewed or often be used in practice.

\subsection{The financial approach}

Methods from the financial approach are traditionally prescribed for the evaluation and selection of all corporate investment proposals (see the standard finance and accounting texts e.g. Bouma [22], Brealy and Myers, [14]; Fox et al. [15]). These methods focus on the incoming and outgoing cash flows as a result of the investment made. Often used methods are:

\section{The payback period}

The payback period is the period between the moment that the IS investment is made and the moment that the total sum of the investment is recovered through the incoming cash flows. The organization decides on a time period within which the sum must be recovered: if it is less than the calculated payback period then it is decided to invest in the proposed project.

\section{The internal rate of return}

The internal rate of return is the threshold at which, after discounting the incoming and outgoing cash flows, the net present value equals zero. If this threshold exceeds the opportunity cost of capital, it is worthwhile to launch the project.

\section{The net present value}

The starting point in the net present value method is the opportunity cost of capital. This rate is used as the discount rate to calculate the net present value. If this

\footnotetext{
${ }^{2}$ An example of this can be found in Clemons and Weber [21].
}

value is larger than zero, it is best to go ahead with the investment.

The latter two methods (often referred to as 'Discounted Cash Flow' (DCF) methods) are seen as superior to financial methods, as they take into account the time value for money. This means that if the moment of receipt of cash flow is further into the future, the value of these cash flows will be less. A decision-maker is considered to have an aversion to risk.

\subsection{The multi-criteria approach}

Apart from financial consequences, an IS investment has non-financial consequences, see Section 2. Intended are positive or negative consequences that cannot or not easily be expressed in monetary terms. Because of the differences between financial and nonfinancial consequences, it is difficult to compare the different consequences on an equal basis. This, however, is a prerequisite for the evaluation of an IS investment proposal and the prioritization of different proposals. Methods from the multi-criteria approach solve this problem by creating one single measure for each investment. Multi-criteria methods are used in many decisionmaking problems and are well known in the capital budgeting literature (see Wissema [23]). A good theoretical treatment of multi-criteria methods, applied in the realm of investments in advanced production technologies is given by Canada and Sullivan [24]. Different variants of multi-criteria methods exist, but the often used methods function as follows:

Before using a multi-criteria method, a number of goals or decision criteria have to be designed. Subsequently, scores have to be assigned to each criterion for each alternative considered. Also the relative importance of each alternative should be established, by means of weights. The final score of an alternative is calculated by multiplying the scores on the different decision criteria with the assigned weights.

In the field of evaluating IS investment proposals. Parker et al. $[25,26]$ have given the multi-criteria approach widespread publicity with their 'Information Economics' method. Although this method has received a lot of attention already, we will briefly discuss the method.

\section{Information economics}

The first criterion of the Information Economics method gives a financial evaluation of a proposed IS investment. Parker et al. call this the enhanced return on investment (ROI). The ROI not only looks at cash flows, arising from cost reduction and cost avoidance, but also provides some additional techniques to estimate incoming cash flows:

- value linking: additional cash flows that accrue to other departments; 
EVALUATION CRITERIA:

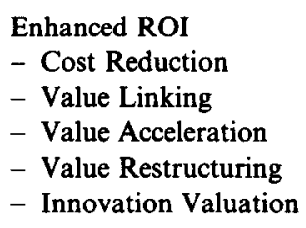

\author{
Business domain \\ - Strategic Match \\ - Competitive Advantage \\ $+\quad$ - Competitive Responses \\ - Management Information \\ - Organizational Risk
}

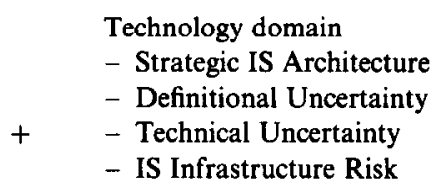

Technology domain

- Strategic IS Architecture

- Technical Uncertainty

- IS Infrastructure Risk

$=$ Value of IS Investment

Fig. 1. The Information Economics method.

- value acceleration: additional cash flows due to reduced time scale for operations;

- value restructuring: additional cash flows through restructuring work and improved job productivity;

- innovation valuation: additional cash flows arising from the innovating aspects of the investment (e.g. competitive advantage);

Furthermore, Parker et al. make a distinction between the "business domain" and the "technology domain". In the two domains several criteria are discerned. To summarize, the total evaluation of the IS investments proposal takes place in three steps, covering financial, business and technological criteria, both positive and negative. (See Fig. 1.)

\section{SIESTA (Strategic Investment Evaluation and Selection Tool Amsterdam)}

The second multi-criteria method that receives a more detailed assessment was designed in the University of Amsterdam [27,28]. The SIESTA method probably is the one of the most comprehensive multi-criteria methods available to the evaluator. The method is supported by several questionnaires and additional software. The evaluation criteria are deduced from a model, in which a distinction is made between the business and the technology domain and three levels of decision-making are discerned. Benefit and risk criteria are deduced from the extent into which the different elements of the model fit. Fig. 2 visualizes the structure of the model.

\subsection{The ratio approach}

In economic research special attention is paid to the possibilities to compare organizational effectiveness by means of ratios (an overview is given by Oonincx [29]). Several ratios have been proposed to assist in IS investment evaluation. Examples of meaningful ratios are: IS expenditures against total turnover and all yieldings that can be attributed to IS investments against total profits. Ratios do not necessarily take only financial figures into account. IS expenditures can, for instance, be related to the total number of employees or to some output measure (e.g. products or services).

\section{The return on management method}

A ratio approach that attracted a lot of attention is

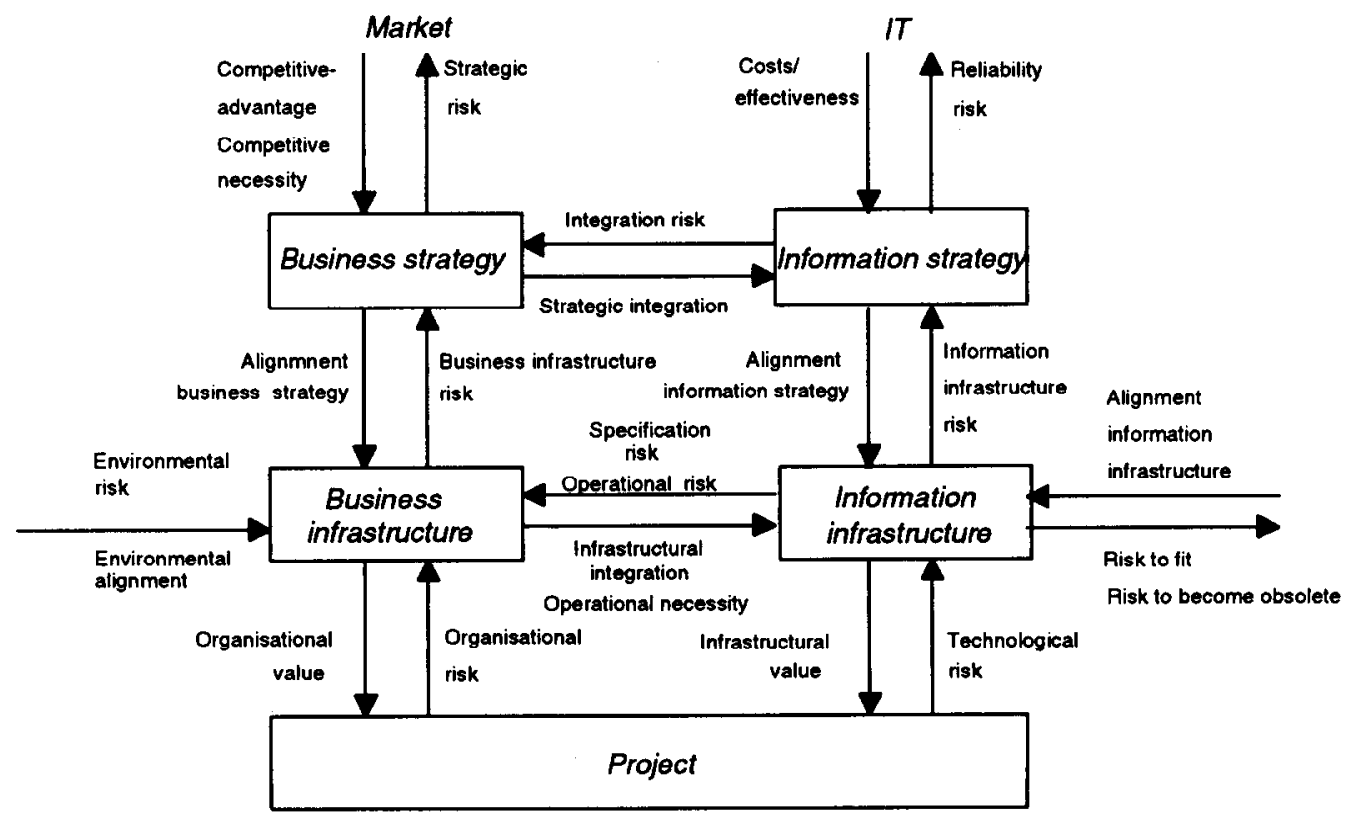

Fig. 2. SIESTA. 


$$
\begin{aligned}
\text { ROM } & =\frac{\text { yieldings }- \text { full operating costs }}{\text { total costs }- \text { full operating costs }} \\
& =\frac{\text { value added by management }}{\text { full cost of management }} \\
& =1+\frac{\text { economic profit before taxes }}{\text { full cost of management }}
\end{aligned}
$$

Fig. 3. The Return of Management method.

the 'Return on Management' (ROM) method of Strassmann [31,32], see also Van Nievelt [32]. The method presupposes that in today's information economy management has become the scarce resource. In the ROM method the value added by management is related to the costs of management. Fig. 3 defines the ROM ratio.

Analysis with the ROM method is supported by the MPIT database, that contains company data of about 300 companies over several years. This database can be used for complete organizational diagnosis or for analysing the impacts of specific investments. Unfortunately the database is not for public use.

\section{IT assessment}

Van der Zee and Koot [33] have designed a method, 'IT assessment', for the evaluation of information technology (IT) effectiveness from a strategic point of view. An important part of the method focuses on the analysis of financial and non-financial ratios. The ratios are subsequently compared with benchmarks; average values that were collected through research in other organizations. These benchmarks are not for public use. The ratios are also used for a historical analysis of the organization and its use of IT. Used this way, the ratios can be of help in decision-making on new IS investments.

\subsection{The portfolio approach}

Portfolios are a well-known decision-making tool in the management literature. A portfolio used in many strategic analyses is the 'Growth Share' portfolio for the positioning of product families of the Boston Consulting Group. It distinguishes between 'wild cats', 'stars', 'cash cows' and 'dogs'. The portfolio methods used in the evaluation of IS investments are all project portfolios, in which investment projects are plotted against several evaluation criteria.

\section{Bedell's method}

Bedell's portfolio method [34-36] subsequently answers three questions:

(1) Should the organization invest in information systems?

(2) In which activities should the organization invest?

(3) Which information systems should be developed?

The central premise of Bedell's method is that a balance is needed between "quality" and "importance". This is also the basis upon which the answers to the three questions are sought. IS investments are more necessary if the relation between the perceived quality of the systems and the importance of information systems is worse.

Information systems are more important if they support important activities and if the activities are more important to the organization. Before the three questions can be answered and calculations are made, several data have to be provided. These data concern:

- The importance of an activity to the organization.

- The importance of information systems to the activities.

- The quality of the information systems in terms of effectiveness and efficiency.

The prioritization of investment proposals is carried out by calculating the contribution of each information system and by plotting three portfolios. The contribution of an IS is defined as the importance of the system multiplied with the improvement of quality after development. To evaluate the value of the investment, a Project-Return index can be calculated, by relating

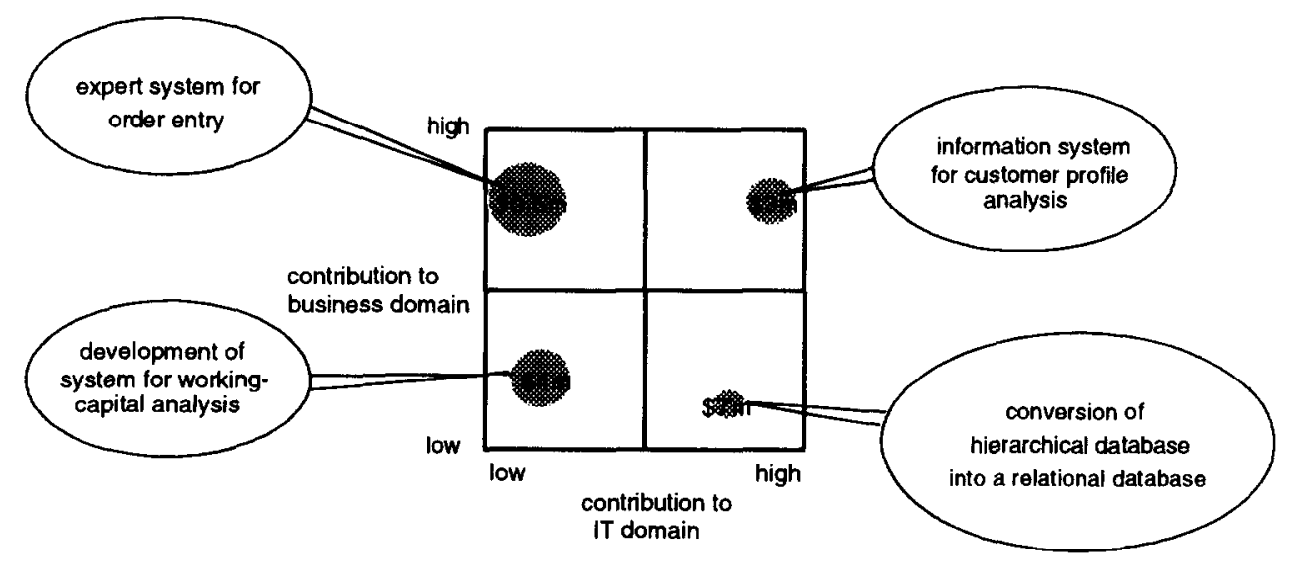

Fig. 4. The Investment Portfolio. 


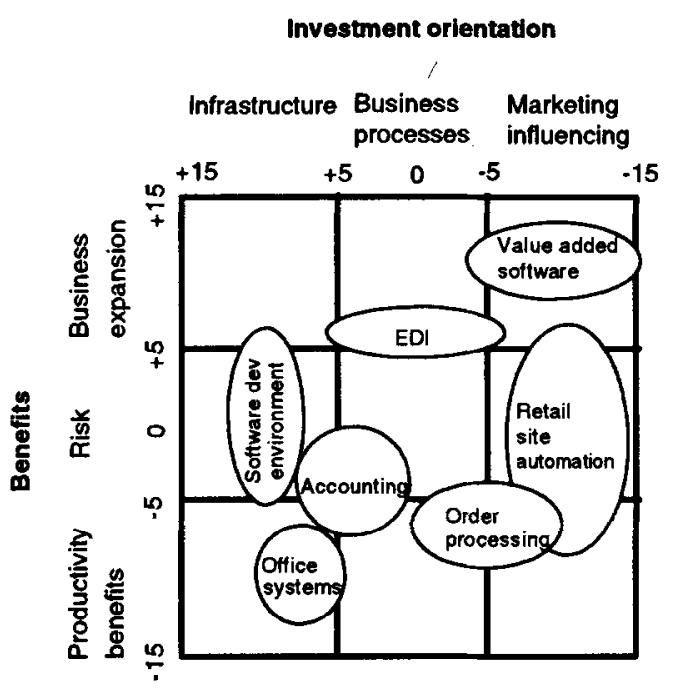

Fig. 5. Investment Mapping.

the contribution of the IS to the development costs. A further review of Bedell's method is provided by Berghout and Renkema [10].

\section{Investment portfolio}

The 'Investment Portfolio' [37] evaluates IS investment proposals on three criteria simultaneously. The three criteria subsequently evaluate:

- The contribution to the business domain.

- The contribution to the technology domain.

- The financial consequences, by means of net present values (NPV) calculation.

The portfolio (see Fig. 4) serves as a framework to make the preferences of the different stakeholders explicit and debatable. Important stakeholders taken into account are: senior management, IT management and the project management of the development project. These three parties subsequently evaluate the investment proposal on one of the three evaluation criteria.

The size of the Net Present Value (NPV) of an IS investment proposal is plotted in the portfolio by means of circle. The larger the circle, the higher the expected NPV. The contribution to the business domain focuses on the long-term benefits, leading to an improvement of the organizations's products or services. The authors suggest that the criteria of the Information Economics method can be used for this. The contribution to the technology domain is assessed by criteria such as: conformance with technology standards, market acceptance of the used technologies and continuity of the suppliers.

In addition to evaluating a single IS investment proposal, the Investment Portfolio is used to compare and prioritize several investment projects. It also offers a risk and sensitivity analysis by varying the size of the circle and by changing the position of a circle.

\section{Investment mapping}

Peters $[38,29]$ designed the 'Investment Map', in which investment proposals are plotted against two main evaluation criteria: the investment orientation and the benefits of the investment. The investment orientation is broken up into infrastructure, business operations and market influencing. The benefits are broken up into enhancing productivity, risk minimalization and business expansion. These categories partly overlap. Fig. 5 gives a visual representation of the Investment Map. The position of an investment proposal on the two axes is determined by a score on the evaluation criteria. The size of the investment in financial terms may be shown by using different colours. A portfolio that has been filled in, it makes the IS investment strategy more explicit.

The 'Investment Map' can also be used to investigate the alignment of the IS investment strategy and the business strategy. To do this, a distinction is made between, for instance, a chance driven or a cost leadership strategy. Additionally, it is possible to do a competitor analysis by plotting the strategies of the main competitors in the portfolio.

\section{Comparison of methods}

This section compares the different approaches and accompanying methods by means of four main characteristics. The reviewed methods are seen as typical examples of the discerned approaches. The characteristics to be discussed are subsequently:

- Objects of the method.

- Evaluation criteria of the method.

- Support of the evaluation process of the method.

- Type of outcome of the method.

Table 2 summarizes the comparison of the methods. In the remainder of this section, the characteristics and the contents of the table will simultaneously be clarified. Furthermore, some general remarks are made regarding the quality of methods for the evaluation of IS investment proposals.

\subsection{Objects of the method}

The objects of the method concern the breadth of the method and type of investment the method can be used for.

\section{Breadth of the method}

With respect to the breadth of the method the following distinction is made:

- Evaluation of the IS project: the method evaluates only specific proposals for IS investments. It is important that a method takes all components of an information 
T.J.W. Renkema, E.W. Berghout/Information and Software Technology 39 (1997) 1-13

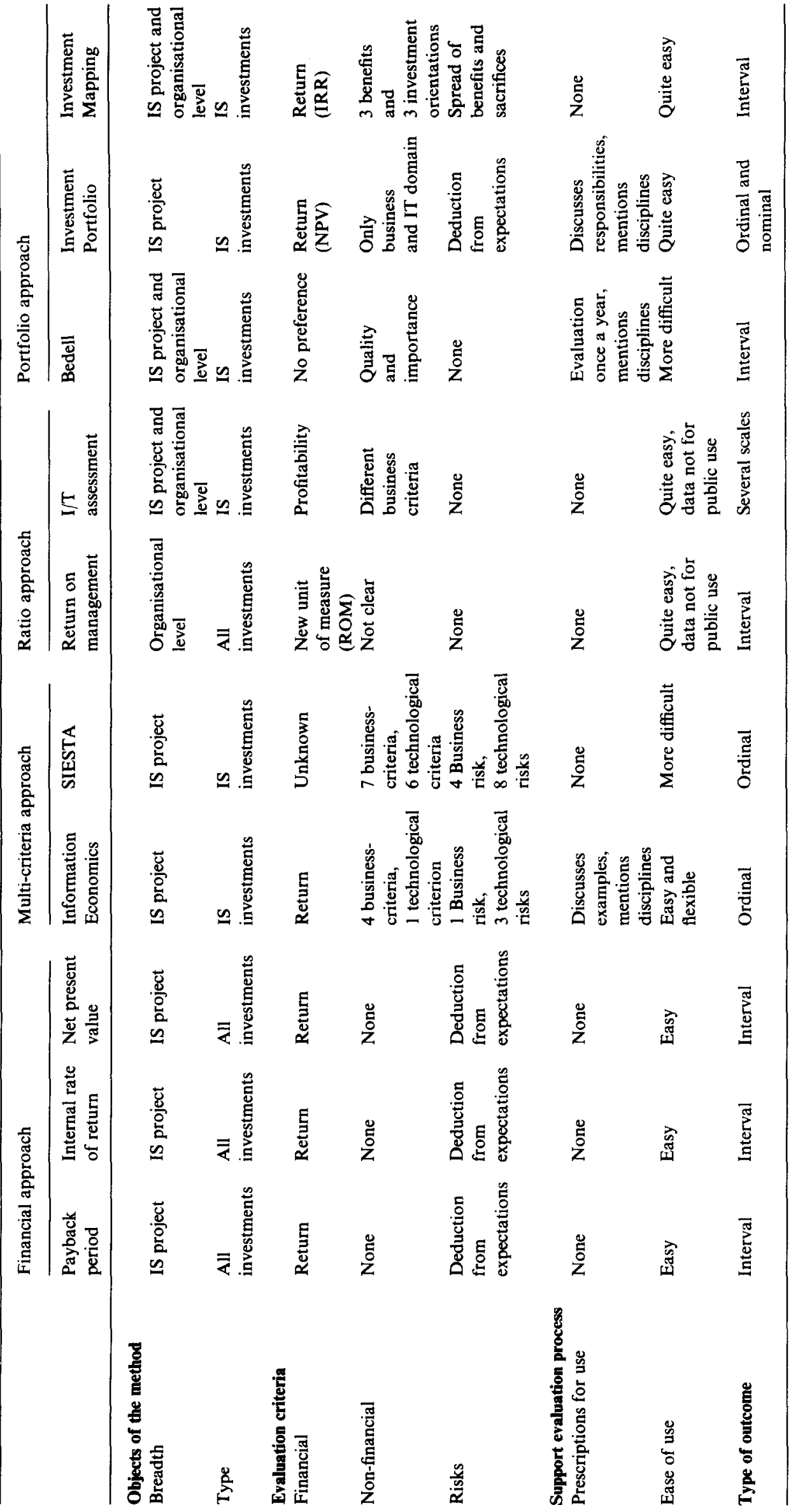


system into account (hardware, software, data, people and procedures). If this is not the case, an incomplete picture of the investment might be given. Most of the methods discussed evaluate specific projects and all take the different components into account.

- Evaluation at an organizational level: the method takes a higher level than the project level into account, for instance by looking at the IT intensity of certain departments. The ROM method and Investment Mapping look at the consequences of investing in IT at the level of the entire organization. Bedell's method and IT Assessment additionally look at separate business processes or activities in the organization.

\section{Type of investment}

A method can be limited with respect to the type of investment it considers. Two limitations are distinguished:

- Organizational investments in general or IS investments in particular. A method can specifically be designed to evaluate IS investments, or the method can be proposed for all investment types.

- Purpose of the IS investment. Investments in information systems can serve different purposes. Butler Cox [30], for instance, distinguish: mandatory investments, investments to improve performance, competitive edge investments, infrastructure investments and research investments. Farbey et al. [19] contend that a major improvement of IS evaluation lies in matching the methods to characteristics of the IS investment, e.g. the purpose of the investment. Table 2 shows that the discussed methods do not take the purpose of the IS investment into account.

\subsection{Evaluation criteria}

The evaluation criteria are the aspects that are addressed in the decision whether to go ahead with the proposed investment. A distinction is made between financial and non-financial consequences and risks (see Section 2.2).

Almost all methods somehow look at financial consequences. With respect to the financial consequences, it is important to know whether the return or the profitability is evaluated.

The different methods take many non-financial consequences into account. All criteria concern business and technological aspects; there are hardly any social or psychological criteria used. Unfortunately, the choice of the criteria is not underpinned by theory.

The methods look at risks in several ways. In Section 2.2 we contended that risk has to do with the uncertainty surrounding the possible consequences of the investment proposal. A risk analysis can, for instance, be carried by calculating the 'best' and 'worst' case or by performing a sensitivity analysis. The methods of the financial approach and the Investment Portfolio both offer opportunities to take risks into account.

In the Information Economics methods risks are viewed as negative consequences and deducted from the benefits. The ROM method, IT Assessment and Bedell's method do not consider them. The SIESTA method uses several criteria with respect to risk but it is not clear as to how these risks should be treated. The Investment Mapping method takes the spread of the possible outcomes into account.

\subsection{Support of the evaluation process}

Support of the evaluation process refers to:

- The extent into which a method indicates or prescribes how it should be used in evaluation practice. Complaints with respect to the evaluation of investment proposals often have to do with how difficult it is to make the possible benefits more tangible. A method might, for instance, suggest possible ways to identify the benefits of the investments, in addition to giving evaluation criteria. Furthermore, support could be given regarding:

- persons to be involved in the evaluation process and their responsibilities;

- collection of data on the right level of detail;

- frequency of evaluations after the proposal stage.

Strikingly, hardly any methods offers substantial support of the evaluation process. This support is often limited to mentioning the different disciplines to be represented (e.g. management, IT staff and end-users).

- The general ease of use of the method. Although all methods attempt to be of help in the evaluation of IS investment proposals, there ease of use can differ a lot. Ease of use can be improved by graphical tools. The method of the financial approach are definitely easy to use, partly because of their reliance on financial measures. The ratio methods are quite easy to use, although the data used for benchmarking are not for public use. Ratio methods seem more appropriate for evaluating the IT contribution to the organization in general. The Information Economics method is easy and flexible to use, while the SIESTA method seems more difficult to use because of the many criteria. The methods of the portfolio approach are also fairly easy to use because of their visual representation, although Bedell's method also requires several more difficult calculations to be made.

\subsection{Type of outcome}

The outcomes of an evaluation method can be measured on the following measurement scales [22]:

- Nominal scale: unities of measures are used to classify 
(for instance the purpose of the investment, see Section 4.1).

- Ordinal scale: unities of measure are used to represent a certain order (for instance the priorities between investment proposals).

- Interval scale: unities of measure are used to represent the differences between the objects (for instance an evaluation in monetary terms).

- Ratio scale: an interval scale with a natural zero (in evaluation of IS investments there is no natural zero, consequently this scale has no relevance).

The higher the scale on which the outcomes are measured, the more unambiguously it can be decided whether it is worthwhile to invest. However, the representation of a proposal on a certain scale also implies the loss of details. This means that the stakeholders in the evaluation process should be convinced that all relevant consequences are accounted for in the outcome.

Most methods of Table 2 measure on an ordinal or interval scale. The Investment Portfolio also measures on a nominal scale and IT Assessment measures on different scales.

\subsection{Quality of evaluation methods}

Preferably conclusions should be drawn concerning the overall quality of the evaluation methods. Because it is difficult to ascribe the success of an IS investment to the use of an evaluation method the quality could, for instance, be assessed by questions such as in [40]:

- Does the method give new insights?

- Does the method give complete results?

- Is the method easy to use?

- Does the method give control over the decisionmaking process?

As our comparison has shown, the discussed methods differ in many aspects. Consequently, general conclusions with respect to the overall quality of the methods cannot be drawn. Furthermore, a more difficult problem lies in the lack of significant validations of the methods in evaluation practice. These validations can give indications of the quality of evaluation methods in terms of relevant evaluation criteria, circumstances in which these should be used and the embeddment of the method in the evaluation process.

\section{Conclusions and recommendations}

\subsection{Conclusions}

Evaluation of IS investment proposals currently is a major issue for both management and academics. This paper has first introduced and defined the concepts used in evaluation. These definitions can be used to improve communication between the different stakeholders in the evaluation process and to gain insight in the differences between the several evaluation methods. The review and comparison of evaluation methods showed that the available methods differ in many respects and that conclusions regarding the overall quality cannot be drawn. However, some general observations can be made:

- The available non-financial evaluation methods are hardly underpinned by theory: they are usually based on single case studies and lack theoretical basis. Consequently, the choice of criteria seems rather arbitrary.

- The available methods focus on the evaluation criteria, less attention is paid to the evaluation process. The experimental study of Klompé and Berghout [41] shows that altering the decision-making process significantly influences decision-making.

- There seems to be trade-off between the inclusion of non-financial criteria and the ease of use of a method. Graphical tools as used in portfolio methods can be of help.

- The differences between the methods can partly be overcome by combining features of the different approaches. For instance, a financial or ratio assessment combined with the non-financial consequences ('contribution') represented in a portfolio.

\subsection{Recommendations}

In order to improve the evaluation of IS investment proposals it is needed to gain knowledge and insight on different aspects. It is important to have a clear view of the relevant evaluation criteria, of the circumstances in which they should be used and of the embeddment of the criteria in the evaluation process. (See also Symons [42], who makes a distinction between the content, process and context of evaluation.) This view can only be gained by validating and improving the evaluation methods in evaluation practice.

We are aware of the difficulties involved in validating evaluation methods in evaluation practice. A major difficulty lies in the causality between the success of an information system and the use of an evaluation method. However, some suggestions can be made. The number of independent variables can be reduced by focusing research on a specific type of investment (e.g. infrastructural investments) or on a line of business (e.g. financial services or public service).

Deeper understanding of what the evaluation process looks like in practice is also a great step forward. A prerequisite for this is the possibility to do research in organizations and to be allowed to publish the insights gained. Progress can only be made by communicating with each other and by exchanging ideas and insights. 
An important observation is that many different interpretations are given to the concepts used in evaluation methods. A good example of this is the use of the term 'cost benefit analysis', which in some cases refers to cash flows and in some cases to costs. One way forward is the use of unambiguous concepts. In evaluation practice it is important to make clear which criteria and which aspects are evaluated to avoid misinterpretations in the course of the evaluation process.

\section{Appendix A: Methods for the evaluation of IS investment proposals}

This appendix is based upon research in the universities of Amsterdam, Delft and Eindhoven, the Netherlands. Although this research has been carried out with the utmost care, the review cannot be exhaustive. New methods are published almost daily and consultancy agencies often use a well-considered method but which is not published because of the possible competitive advantage. Furthermore, several methods combine features of other methods. For some methods the original source is not given, but is referred to in articles or books in which the method is mentioned or reviewed. The list of references is not an exhaustive one, but it has been strived for to give the best references, preferably from the IS literature. Also, not all methods are specifically designed for the evaluation of IS investment proposals.

\section{Method}

Accounting rate of return:

Analytic hierarchy process:

Application benchmark technique:

Application transfer team:

Automatic value points:

Balanced scorecard:

Bayesian analysis:

Bedell's method:

Buss's method:

Benefits-risk portfolio:

Benefit assessment grid:

Breakeven analysis:

Boundary value:

Cost benefit analysis:

Cost benefit ratio:

Cost displacement/avoidance:

Cost effectiveness analysis:

Cost-value technique:

Cost-revenue analysis:

Critical success factors:

Customer resource life cycle:

Decision analysis:

Delphi evidence:

Executive Planning for Data Processing:

Functional Analysis of Office Requirements:

Gameplaying:

Hedonic wage model:

Information Economics:

Internal rate of return:

Investment mapping:

Investment portfolio:

Information systems investment strategies:

Knowledge based system for IS evaluation:

MIS utilization technique:

Multi-objective, multi-criteria methods:

Net present value:

Option theory:

Payback Time:

\section{References}

Bacon [5]

Saaty [43]; in: Carter [44]

in: Powell [17]

in Lincoln [45]

in: Lincoln [45]

Kaplan and Norton [46]; in Douglass and Walsh [47]

Kleijnen [48]

Bedell [34]; in: van Reeken [36]

Buss [49]

McFarlan and McKenney [50]; in: Swinkels and van Irsel [9] Huigen and Jansen [51]

Sassone [52]

in: Farbey et al. [6,19]

King and Schrems [53]; Sassone and Schaffer [54]

Yan Tam [7]

in: Sassone [52]

in: Sassone [52]

Joslin [12]

in: Farbey et al. [6]

Rockart [55]

Ives and Learmonth [56]; in: Hochstrasser and Griffiths [4]

in: Sassone [52]; in: Powell [17]

in: Powell [17]

in: Lincoln [45]

Schaeffer et al. [57]

in: Farbey et al. [6]

in: Sassone [52]

Parker et al. [25,26]

Brealey and Myers [14]; Fox et al. [15]

Peters [38,39]

Berghout and Meertens [37]

in: Lincoln [45]

Agarwal et al. [58]

in: Powell [17]

in: Farbey et al. [6]; Vaid-Raizada [59]

Brealey and Myers [14]; Fox et al. [15]

Dos Santos [60]; Kambil et al. [61]

Brealey and Myers [14]; Fox et al. [15] 
Potential problem analysis:

Profitability index:

Process quality management:

Quality engineering:

Return on investment:

Return on management:

Requirements-costing technique:

Schumann's method:

SESAME:

Seven milestone approach:

SIESTA:

Strategic application search:

Strategic option generator:

Systems investment methodology:

Simulation:

Socio-technical project selection:

Satisfaction and priority survey:

Structural models:

System dynamics analysis:

Systems measurement:

Time savings times salary:

User utility function assessment technique:

Value analysis:

Value chain analysis:

Ward's portfolio analysis:

Wissema's method:

Zero based budgeting:

\section{References}

[1] M.J. Earl, Management Strategies for Information Technology, London, Prentice-Hall, 1989.

[2] Th. J. Davenport and J.E. Short, The new industrial engineering: information technology and business process redesign, Sloan Management Review (Summer 1990) 11-27.

[3] P.G.W. Keen, Shaping the Future: Business Design Through Information Technology, Harvard Business School Press, 1991.

[4] B. Hochstrasser and C. Griffiths, Regaining Control of IT Investments, A Handbook for Senior UK Management, London, Kobler Unit, Imperial College, 1990.

[5] C.J. Bacon, The use of decision criteria in selecting information systems/technology investments, MIS Quarterly (September, 1991).

[6] B. Farbey, F. Land and D. Targett, Evaluating investments in IT. J. of Information Technology, 7 (1992) 109-122.

[7] K. Yan Tam, Capital budgeting in information system development. Information and Management, 23 (1992) 345-357.

[8] L. Willcocks and S. Lester, Evaluating the feasibility of information technology investments, Research Report RDP93/1, Oxford Institute of Information Management, 1993.

[9] G.J.P. Swinkels and van Irsel, H.G.P., Investeren in informatietechnologie, take IT or leave IT (Investments in information technology, take IT or leave IT; in Dutch), Compact (Summer 1992) 3-13.

[10] E.W. Berghout and T.J.W. Renkema, Beoordelen van voorstellen voor investeringen in informatiesystemen (Evaluating information systems investment proposals: in Dutch), Research Report, Delft University of Technology, 1994.

[11] A.B. Frielink (ed.), Auditing Automatic Data Processing, Amsterdam, Elsevier, 1961. in: Powell [17]

Bacon [5]

in: Lincoln [45]

Hochstrasser [62]

Brealey and Myers [14]; Farbey et al. [6]

Strassmann [31]; van Nievelt [32]

Joslin [12]

in: Swinkels and von Irsel [9]

Lincoln [63]; Lincoln and Shorrock [64]

Silk [65]

Irsel et al. [27,28]

in: Lincoln [45]

Wiseman [66]

in: Lincoln [45]

Kleijnen [48]; in: Farbey et al [6]; in: Powell [17]

Udo and Guimaraes [67]

in: Lincoln [45]

in: Sassone [52]

Wolstenhome et al. [68]

Spraque en Carlson [69]; in: Powell [17]

in: Sassone [52]

in: Powell [17]

Keen [70]

Porter [71]

Ward [72]

Wissema [23]

in: Zmud [73]

[12] E.O. Joslin, Computer Selection, London, Addison-Wesley, 1968.

[13] B.K. Brussaard, Organisatie van de informatievoorziening (Organization of Information Processing; in Dutch), Department of Mathematics and Computer Science, Delft University of Technology, 1993.

[14] R.A. Brealey and S.C. Myers, Principles of Corporate Finance, New York, McGraw-Hill, 1988.

[15] R. Fox, A. Kennedy and K. Sugden, Decision Making, A Management Accounting Perspective, Oxford, ButterworthHeinemann, 1990.

[16] J.R. Meredith and M.M. Hill, Justifying new manufacturing systems: a managerial approach, Sloan Management Review (Summer 1987).

[17] P. Powell, Information technology evaluation, is it different? J. Operational Research Society, 1 (1992) 29-42.

[18] L. Willcocks, Evaluating information technology investments: research findings and reappraisal, J. Information Systems, 2 (1992) 243-268.

[19] B. Farbey, F. Land and D. Targett, How to Assess Your IT Investment. A Study of Methods and Practice, Oxford, ButterworthHeinemann, 1993.

[20] T.J.W. Renkema, Evaluation of investments in information technology, preliminary research findings. Proc. 4th European Software Cost Modelling Meeting, Bristol, 1993.

[21] E.K. Clemons and B.W. Weber, Strategic information technology investments, guidelines for decision making. J. of Management Information Systems, 2 (1990) 9-28.

[22] J.L. Bouma, Leerboek der bedrijfseconomie, deel II (Textbook on Business Economics, part II: in Dutch), Wassenaar, Delwel, 1980.

[23] J.G. Wissema, An Introduction to Capital Investment Selection, London, Francis Pinter, 1985.

[24] J.R. Canada and W.G. Sullivan, Economic and Multiattribute 
Evaluation of Advanced Manufacturing Systems, Prentice-Hall, Englewood Cliffs, 1989.

[25] M.M. Parker, R.J. Benson and H.E. Trainor, Information Economics, Linking Business Performance to Information Technology, New Jersey, Prentice-Hall, 1988.

[26] M.M. Parker, R.J. Benson and H.E. Trainor, Information Strategy and Economics, New Jersey, Prentice-Hall, 1989.

[27] H.G.P. Irsel, P. Fluitsma and P.N.A. Broshuis, Evaluatie van IT investeringen: het afstemmen van vraag en aanbod (IT investment evaluation: aligning supply and demand; in Dutch), theme issue on IT investment evaluation, Informatie (1992a) 716-726.

[28] H.G.P. Irsel and P. Fluitsma, Het plannen en rechtvaardigen van infrastructurele IT-investeringen (Planning and justification of infrastructural IT investments; in Dutch), Compact (Summer 1992b) 38-48.

[29] J.A.M. Oonincx, Kengetallen en financiële ratio analyse (Ratios and financial ratio analysis; in Dutch), Financiële Lieding en Organisatie, (January 1982) 2370-2372.

[30] Butler Cox Foundation, Getting value from information technology, Research report 75, 1990.

[31] P.A. Strassmann, Information Payoff, New York, Free Press, 1990.

[32] M.C.A. van Nievelt, Managing with information technology, a decade of wasted money? Compact (Summer 1992) 15-24

[33] H.T.M. van der, Zee and W.J.D. Koot, I/T-assessment, een kwalitatieve en kwantitatieve evaluatie van de informatieverzorging vanuit een strategisch perspectief (I/T assessment, a quantitive and qualitative evaluation of information processing from a strategic perspective; in Dutch), Informatie, 11 (1989) $805-900$.

[34] E.F. Bedell, The Computer Solution: Strategies for Success in the Information Age, Homewood, Dow-Jones Irwin, 1985.

[35] 1. Delahaye and van Reeken, A.J., Waarom investeren in welke informatiesystemen? Een vergelijkende toepassing van 'Bedell' en 'Parker/Benson/Trainor' bij De Gazet (Why invest in which information systems, a comparison of 'Bedell' and 'Parker/Benson/ Trainor at The Gazet; in Dutch), theme issue on IT investment evaluation, Informatie (1992) 655-670.

[36] van Reeken, A.J., Investeringsselectie van informatiesystemen, de methode van Eugene Bedell (Selection of investments in information systems, Eugene Bedell's method; in Dutch), Handboek BIK, (1992) 1030-1032.

[37] E.W. Berghout and F.J.J. Meertens, Investeringsportfolio voor het beoordelen van voorstellen van informatiesystemen (Investment portfolio for the evaluation of IS investment proposals), theme issue on IT investment evaluation; in Dutch), Informatie, (1992) 677-691.

[38] G. Peters, Evaluating your computer investment strategy. J. Information Technology (September 1988).

[39] G. Peters, The evaluation of information technology projects, PhD Thesis, Brunel University, 1989.

[40] J.S. Carrol and E.J. Johnson, Decision Research, a Field Guide, Newsbury Park, SAGE, 1990.

[41] R. Klompe and E.W. Berghout, Method is a critical success factor for IS evaluation, in: A. Brown and D. Remenyi (eds.) Proc. 2nd European Conf. on IT Investment Evaluation, Henley on Thames, UK, 1995

[42] V.J. Symons, A review of information system evaluation: content, context, and process, European Journal of Information Systems, i (1991) 205-212.

[43] T.L. Saaty, The Analytic Hierarchy Process, New York, MçGraw Hill, 1980.

[44] W.K, Carter, To invest in new technology or not? New tools for making the decision. J. of Accountancy, May (1992) 58-62.

[45] T.J. Lincoln, Managing Information Systems for Profit, Chichester, John Wiley, 1990
[46] R.S. Kaplan and D.P. Norton, The balanced scorecard measures that drive performance, Harvard Business Review, (Jan-Feb. 1992) 71-79.

[47] D.P. Douglas and L. Walsh, Basic principles for measuring IT value, I/S Analyzer, 10 (1992).

[48] J.C.P. Kleijnen, Computers and Profits, Reading, MA, AddisonWesley, 1980.

[49] M.D.J. Buss, How to rank computer projects, Harvard Business Review (January-February, 1983).

[50] F.W. McFarlan and J.L. McKenney, Corporate Information Systems Management. The Issues Facing Senior Executives, Homewood, Dow Jones Irwin, 1983.

[51] J. Huigen and G.S.H. Jansen, De baten van informatiesystemen (The benefits of information systems; in Dutch), ESB, 3/7, 1991.

[52] P.G. Sassone, A survey of cost-benefit methodologies for information systems, Project Appraisal, 2 (1988) 73-84.

[53] J.L. King and E.L. Schrems, Cost-benefit analysis in information systems development and operation. Computing Surveys, 10 (1978) 19-34.

[54] P.G. Sassone and W.A. Schaffer, Cost-Benefit Analysis: A Handbook, New York, Academic Press, 1978.

[55] J.F. Rockart, Chief executives define their own data needs, Harvard Business Review (March-April 1979) 81-93.

[56] B. Ives and $G$. Learmonth, The information system as a competitive weapon, Comm. ACM, 12 (1984) 1193-1201.

[57] G. Schaefer (ed.), Functional analysis of office requirements: a multiperspective approach, Chichester, John Wiley, 1988.

[58] R. Agarwal, M.R. Tanniru and M. Dacruz, Knowledge-based support for combining qualitative and quantitative judgments in resource allocation decisions. J. Management Information Systems, 1 (1992) 165-184.

[59] V.K. Vaid-Raizada, Incorporation of intangibles in computer selection decisions, J. Systems Management (November, 1983) $30-36$.

[60] B.L. Dos Santos, Justifying investments in new information technologies. J. of Management Information Systems, 4 (1991) 71-90.

[61] A. Kambil, J. Henderson and H. Mohsenzadeh, Strategic management of information technology investments: an options perspective, in Banker et al. 1993.

[62] B. Hochstrasser, Quality engineering: a new framework applied to justifying and prioritizing IT investments. European Journal of Information Systems, 3 (1993) 211-223.

[63] T.J. Lincoln, Do computer systems really pay-off?, Information and Management, 11 (1986) 25-34.

[64] T.J. Lincoln and D. Shorrock, Cost justifying current use of information technology, in Lincoln T.J. [45], pp. 309-330.

[65] D.J. Silk, Managing IS benefits for the 1990s. J. Information Technology, (1990) 185-193.

[66] C. Wiseman, Strategy and Computers, Information Systems as Competitive Weapons, Homewood, Dow Jones Irwin, 1985.

[67] G. Udo and T. Guimaraes, Improving project selection with a socio-technical approach, IRMA Conference Proceedings, 1992, pp. 204-213.

[68] E.F. Wolstenholme et al., The design, application and evaluation of a system dynamics based methodology for the assessment of computerised information systems. European Journal of Information Systems, 5 (1992) 341-350.

[69] R.H. Spraque and E.D. Carlson, Building Effective Decision Support Systems, Englewood Cliffs, Prentice-Hall, 1982.

[70] P.G.W. Keen, Value analysis: justifying decision support systems, MIS Quarterly, (March 1981).

[71] M.E. Porter, Competitive Advantage, Creating and Sustaining Superior Performance, New York, The Free Press, 1985.

[72] J.M. Ward, A portfolio approach to evaluating information systems investments and setting priorities. J. Information Technology, (1990) 222-231. 
[73] R.W. Zmud, Information Systems in Organizations, Scott, Foresman, 1983.

[74] R.D. Banker, R.J. Kauffman and M.D. Mahmood, Strategic Information Technology Management, Harrisburg, Idea Group Publishing, 1993.
[75] J.D. Mckeen and H.A. Smith, The value of information technology: a resource view, Proc. ICIS, 1991.

[76] J. Harrington, Organizational Structure and Information Technology, London, Prentice-Hall, 1991 